\title{
Optimal block designs for diallel crosses
}

\author{
M. K. Sharma · Sileshi Fanta
}

Received: 9 June 2008 / Published online: 26 February 2009

(C) The Author(s) 2009. This article is published with open access at Springerlink.com

\begin{abstract}
Dey and Midha (Biometrika 83(2):484-489, 1996) constructed optimal block designs for complete diallel cross experiment using triangular partially balanced incomplete block designs with two associate classes. They listed optimal block designs for the lines in the range from $5 \leq v \leq 10$. In this paper, we are also proposing additional optimal block designs for complete diallel cross experiment using two associate class partially balanced block designs for some additional values of $v$. Our method yields designs for proper and non-proper settings for complete diallel cross experiments. The proper and non proper designs are optimal in the sense of Kempthorne (Genetics 41:451-459, 1956) and non-proper designs are universally optimal in the sense of Kiefer (A survey of statistical design and linear models, North Holland, Amsterdam, 1975). The list of practically important designs is also given.
\end{abstract}

Keywords Partially balanced incomplete block design - Complete diallel cross . General combining ability · Mating-environment design · Auxiliary design . Efficiency

\section{Introduction}

A diallel cross consists of all possible crosses between a numbers of varieties. Reciprocal crosses and the selfed parents may or may not be omitted. Diallel crosses as a mating design is used to study the genetic properties of inbred lines in plant breeding experiments.

M. K. Sharma $(\varangle) \cdot$ S. Fanta

Department of Statistics, Addis Ababa University,

P.B. No. 1176, Addis Ababa, Ethiopia

e-mail:mk_subash@yahoo.co.in 
Among the four types of diallels discussed by Griffing (1956), system IV is the most commonly used in plant breeding. Suppose there are $v$ lines and let us consider a cross of the form $i \times j$ with $i<j=1, \ldots, v$. With all possible $n_{c}=v(v-1) / 2$ crosses. This is sometimes referred to as the modified or half-diallel. We shall refer to it as a complete diallel cross (CDC).

The common practice with diallel cross experiment is to evaluate the crosses in completely randomized designs or randomized complete block designs as environment designs, e.g. Kempthorne and Curnow (1961). Due to limitation of homogeneous experimental units in a block to accommodate all the chosen crosses, the estimate of genetic parameters would not be precise enough if a complete block design was adopted for large number of crosses. To overcome this problem, many researchers used balanced incomplete block (BIB) designs, partially balanced incomplete block (PBIB) designs with two associate classes etc. by treating the crosses as treatments. These designs have interesting optimality properties when making inferences on a complete set of orthonormalised treatment contrasts. However, in diallel cross experiments the interest of the experimenter is in making comparisons among general combining ability (gca) effects of lines and not crosses and therefore, using these designs as mating designs may result into poor precision of the comparison among lines. Further, the analysis of a diallel cross experiment in incomplete block depends on the incidence of lines rather than the incidence of the crosses as treatments with in a block. It is therefore apparent that special techniques are required to obtain good designs for diallel crosses experiments.

Several authors such as Gupta and Kageyama (1994), Dey and Midha (1996), Mukerjee (1997), Das et al. (1998), Parsad et al. (1999) and Sharma (2004) addressed the problem of finding optimal designs by using nested incomplete block designs (NBIB), triangular PBIB designs, nested balanced block (NBB) designs, GD PBIB designs and circular designs, etc. Gupta and Kageyama (1994) and Sharma (2004) reported optimal designs in which every cross is replicated once but their designs differ in their parametric values with proposed designs. Das et al. (1998) and Parsad et al. (1999) reported optimal designs for single as well more replications. Dey and Midha (1996) reported optimal and efficient designs in which the crosses are replicated in the range $3 \leq r \leq 10$. These designs also differ in parametric values of our proposed designs.

We, in this paper, derive additional incomplete block designs for the same mating designs, using two associate class PBIB designs such that none of the $\lambda$ 's is zero. We have also listed these designs for reasonable practically usable values along with designs reported by these authors. The model considered involves only the gca effects. The specific combining ability (sca) effects being excluded from the model because the derived designs are not connected for cross effects. The paper is structured as: (1) the method of construction of designs is presented in Sect. 2, (2) in Sect. 3 analysis and optimality of the designs is considered and we show that the non-proper designs have strong optimality properties, (3) in Sect. 4, the efficiency factor of both designs (proper and non-proper) as compared to randomized block designs is considered. For definition and properties of PBIB design, see Dey (1986) 


\section{Method of construction}

The method is simply stated as: from tables of Clatworthy (1973), take for $v$ lines under evaluation and numbered randomly, a two associate PBIB design with parameters $v=b, r=k, \lambda_{1}, \lambda_{2}, n_{1}, n_{2}, p_{j k}^{i}(i, j, k=1,2)$ having none of the $\lambda$ 's equal to zero and also with the property that any pair of treatments does not occur more than once in any column of the design when we consider block size $k$ as a blocks. We call this design as an auxiliary design. This feature of the auxiliary design helps us to construct a block design for CDC.

Now in auxiliary design, take all possible distinct pair of combinations of treatments in each block, starting from the first treatment of the block. These give $k(k-1) / 2$ pairs per block. Thus we get resulting design in which $b k(k-1) / 2$ pairs arranged in $b$ blocks, each containing $k(k-1) / 2$ pairs. Now in resulting block design identify these pairs of treatments as crosses by treating treatments of the original design as lines. Now we consider in resulting design, the number of plots $(=k(k-1) / 2)$ as blocks and number of blocks $(b=v)$ as the block size of each $k(k-1) / 2$ blocks. We call this arrangement as mating design and denote it as $d$. Since $\lambda$ 's are unequal, it leads to unequal repetition of the crosses in design $d$. The total number of crosses in mating design $d$, is $b k(k-1) / 2$ and out of these $v n_{i} / 2$ crosses are appearing in $n_{i} \lambda_{i} / 2$ blocks $(i=1,2)$. Since replications of crosses are unequal, it makes mating design unbalanced for CDC experiment. To make the design balanced for CDC experiment, we will have to make the replications of the crosses equal because in balanced designs each elementary contrast among gca effects is estimated with equal precision under the assumptions of homogeneous error variance across all blocks. To do this, if $\lambda_{1}>\lambda_{2}$ we delete $\frac{1}{2}\left[n_{1}\left(\lambda_{1}-\lambda_{2}\right)\right]$ blocks, (or, if $\lambda_{2}>\lambda_{1}$ then $\frac{1}{2}\left[n_{2}\left(\lambda_{2}-\lambda_{1}\right)\right]$ ) from $k(k-1) / 2$ blocks in design $d$.

In some auxiliary designs, for $v$ even lines, if $\left(\lambda_{1}-\lambda_{2}\right)$ (or $\left.\left(\lambda_{2}-\lambda_{1}\right)\right)$ is odd, then $n_{1}$ (or $n_{2}$ ) is also odd, then the expression of number of blocks to be deleted, will not be a positive integer but it will be equal to some positive integer \pm 0.5 . So in this case we will have to delete blocks equal to some value of positive integer and 0.5 fraction of one of the block which contains repeated crosses i.e. number of crosses to be deleted are equal to $v \times$ (value of the integer $\pm v / 2$ ). The process of deletion of blocks will be done with the help of association schemes of auxiliary designs (i.e PBIB designs). Now we may classify our auxiliary designs into two classes (1) where $\left[n_{1}\left(\lambda_{1}-\lambda_{2}\right)\right]$ and $\left[n_{2}\left(\lambda_{2}-\lambda_{1}\right)\right]$ are both positive even integers and (2) where $\left[n_{1}\left(\lambda_{1}-\lambda_{2}\right)\right]$ and $\left[n_{2}\left(\lambda_{2}-\lambda_{1}\right)\right]$ are both odd positive integers. We denote both these auxiliary designs as $d_{(1)}$ and $d_{(2)}$.

Thus the process of deletion of blocks of repeated crosses will yield two types of mating-environment designs (proper and non-proper) for CDC experiments with parameters.

(i) $v_{1}=v(v-1) / 2, b_{1}=\lambda_{2}(v-1)$ if $\lambda_{1}>\lambda_{2}\left(\right.$ or $\lambda_{1}(v-1)$ if $\left.\lambda_{2}>\lambda_{1}\right), r_{1}=\lambda_{2}$ (or $\left.\lambda_{1}\right), k_{1}=v$

(ii) $v_{2}=v(v-1) / 2, b_{2}=\lambda_{2}(v-1)$ if $\lambda_{1}>\lambda_{2}\left(\right.$ or $\lambda_{1}(v-1)$ if $\left.\lambda_{2}>\lambda_{1}\right), r_{2}=\lambda_{2}$ (or $\left.\lambda_{1}\right), k_{2}=(v, v / 2)$ 


\begin{tabular}{lccc}
\multicolumn{4}{c}{ Plan (auxiliary } \\
$B_{1}$ & 1 & 2 & 4 \\
$B_{2}$ & 2 & 3 & 5 \\
$B_{3}$ & 3 & 4 & 1 \\
$B_{4}$ & 4 & 5 & 2 \\
$B_{5}$ & 5 & 1 & 3
\end{tabular}

Treatment
1
2
3
4
5

First associate

2,5

1,3

2, 4

3,5

1,4

Design $d_{1}$ (mating-environment design)

Design $d$

$\begin{array}{lll}B_{1} & B_{2} & B_{3} \\ 1 \times 2 & 1 \times 4 & 2 \times 4 \\ 2 \times 3 & 2 \times 5 & 3 \times 5 \\ 3 \times 4 & 3 \times 1 & 4 \times 1 \\ 4 \times 5 & 4 \times 2 & 5 \times 2 \\ 5 \times 1 & 5 \times 3 & 1 \times 3\end{array}$

$\begin{array}{ll}B_{1} & B_{2} \\ 1 \times 2 & 1 \times 4 \\ 2 \times 3 & 2 \times 5 \\ 3 \times 4 & 3 \times 1 \\ 4 \times 5 & 4 \times 2 \\ 5 \times 1 & 5 \times 3\end{array}$

Second associate 3,4

4,5

1,5

1,2

2, 3

\begin{tabular}{lccc}
\multicolumn{4}{c}{ Plan (auxiliary design } \\
$\left.d_{(2)}\right)$ \\
$B_{1}$ & 1 & 2 & 4 \\
$B_{2}$ & 2 & 3 & 5 \\
$B_{3}$ & 3 & 4 & 6 \\
$B_{4}$ & 4 & 5 & 1 \\
$B_{5}$ & 5 & 6 & 2 \\
$B_{6}$ & 6 & 1 & 3
\end{tabular}

$\begin{array}{ll}\text { Treatment } & \text { First associate } \\ 1 & 4 \\ 2 & 5 \\ 3 & 6 \\ 4 & 1 \\ 5 & 2 \\ 6 & 3\end{array}$

Second associate

2, 3, 5, 6

$1,3,4,6$

$1,2,4,5$

$2,3,5,6$

$1,3,4,6$

$1,2,4,6$

Design $d$

$\begin{array}{llllll}\text { Design } d & & & & \text { Design } d_{2} & \text { mating-environment des } \\ B_{1} & B_{2} & B_{3} & B_{1} & B_{2} & B_{3} \\ 1 \times 2 & 1 \times 4 & 2 \times 4 & 1 \times 2 & 1 \times 4 & 2 \times 4 \\ 2 \times 3 & 2 \times 5 & 3 \times 5 & 2 \times 3 & 2 \times 5 & 3 \times 5 \\ 3 \times 4 & 3 \times 6 & 4 \times 6 & 3 \times 4 & 3 \times 6 & 4 \times 6 \\ 4 \times 5 & 4 \times 1 & 5 \times 1 & 4 \times 5 & & 5 \times 1 \\ 5 \times 6 & 5 \times 2 & 6 \times 2 & 5 \times 6 & & 6 \times 2 \\ 6 \times 1 & 6 \times 3 & 1 \times 3 & 6 \times 1 & & 1 \times 3\end{array}$

We denote both designs as $d_{1}$ and $\mathrm{d}_{2}$. The method of construction is illustrated below by two examples.

Example 1 For illustration, we consider design C12 (Clatworthy 1973) with parameters $v=b=5, r=k=3, n_{1}=n_{2}=2, \lambda_{1}=1$ and $\lambda_{2}=2$. The plan and association scheme of the design is given below:

Since $\lambda_{2}=2$, the crosses $(1 \times 3),(1 \times 4),(2 \times 4),(2 \times 5)$ and $(3 \times 5)$ appeared in both blocks 2 and 3 of design $d$. So we will delete one of the blocks to obtain M-E design $d_{1}$.

Example 2 For second type of design, we consider design R 42 (Clatworthy 1973) with parameters $v=6, r=3, k=3, b=6, m=3, n=2, \lambda_{1}=2$ and $\lambda_{2}=1$.

Since $\lambda_{1}=2$, the crosses $(1 \times 4),(2 \times 5)$, and $(3 \times 6)$ appeared repeatedly in block 2 of design $d$. So we will delete these crosses from block 2 to keep the replication same for all crosses. Thus we obtain $d_{2}$. 


\section{Analysis and optimality}

For convenience in further discussion, we will denote both designs $d_{1}$ and $d_{2}$ as $d^{*}$. The data obtained from the design $d^{*}$, we take the following model:

$$
\mathbf{Y}=\mu \mathbf{1}_{\mathbf{n}}+\boldsymbol{\Delta}_{1} \mathbf{g}+\boldsymbol{\Delta}_{2} \boldsymbol{\beta}+\mathbf{e}
$$

where $\mathbf{Y}$ is the $n \times 1$ observational vector, $\mu$ is the general mean, $\mathbf{1}_{n}$ denotes an $n$ component vector of 1 's, $\mathbf{g}=\left(g_{1}, \ldots, g_{v}\right)^{\prime}$ and $\beta=\left(\beta_{1}, \ldots, \beta_{b}\right)$ are the vector of $v$ gca effects and $b\left(=b_{1}=b_{2}\right)$ block effects respectively. $\boldsymbol{\Delta}_{1}$ and $\boldsymbol{\Delta}_{2}$ are the corresponding design matrices of of $n \times v$ and $n \times b$, respectively; that is $(s, i)$ th element of $\Delta_{1}$ is 1 if the cross in the $s$ th experimental unit has one parent $i$ and is 0 otherwise. Similarly $(s, u)$ th element of $\boldsymbol{\Delta}_{2}$ is 1 if the cross in the $s$ th experimental unit comes from $u$ th block and 0 otherwise. $\mathbf{e}$ is a random vector of error components and takes care of specific combining ability as well as unassignable variation and distributed with mean 0 and constant variance $\sigma^{2}$.

For $1 \leq i<j \leq v$, let $g_{d^{*} i j}$ is the number of times cross $(i \times j)$ occurs in $d^{*}$. Let $s_{d^{*} i}$ be the number of times the $i$ th line occurs in design $d^{*}$.

Following Gupta and Kageyama (1994), it can be shown that the information matrix for $\mathbf{g}$ under $d^{*}$ is

$$
\mathbf{C}_{d^{*}}=\mathbf{G}_{d^{*}}-v^{-1} \mathbf{N}_{d^{*}} \mathbf{N}_{d^{*}}
$$

where $\boldsymbol{\Delta}_{1}^{\prime} \boldsymbol{\Delta}_{1}=\mathbf{G}_{d^{*}}=\left(\mathbf{g}_{d^{*} i j}\right), \mathbf{g}_{d^{*} i i}=s_{d^{*} i}$ and $\boldsymbol{\Delta}_{1}^{\prime} \boldsymbol{\Delta}_{2}=\mathbf{N}_{d^{*}}=\left(n_{d^{*} i j}\right)$ is the $v \times b$ matrix of parental lines versus blocks, $n_{d^{*} i j}$ is the number of times line $i$ occurs in block $u$.

Under the model, the reduced normal equations for gca, using design $d^{*}$, are

$$
\mathbf{C}_{d^{*}} \hat{\mathbf{g}}=\mathbf{Q}
$$

where $\mathbf{Q}=\mathbf{T}-v^{-1} \mathbf{N}_{d^{*}} \mathbf{B}$. Here $\mathbf{T}$ is the vector of line total and $\mathbf{B}$ is the vector of block totals. Following Dey and Midha (1996) we now have the following results which will

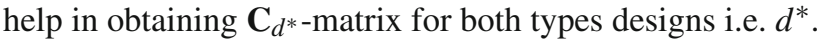

Lemma 3.1 For the design $d^{*}$, the following are true.

$$
\begin{gathered}
\sum_{u=1}^{b} n_{i l}=\lambda_{1}\left(n_{1}+n_{2}\right)=\lambda_{1}(v-1) \quad \text { if } \lambda_{2}>\lambda_{1} \\
=\lambda_{2}\left(n_{1}+n_{2}\right)=\lambda_{2}(v-1) \quad \text { if } \lambda_{1}>\lambda_{2} \\
\sum_{i=1}^{v} n_{i l}=2 v
\end{gathered}
$$




$$
\begin{aligned}
\sum_{u=1}^{b} n_{i l}^{2} & =2 \lambda_{1}\left(n_{1}+n_{2}\right)=2 \lambda_{1}(v-1) \text { if } \lambda_{2}>\lambda_{1} \\
& =2 \lambda_{2}\left(n_{1}+n_{2}\right)=2 \lambda_{2}(v-1) \text { if } \lambda_{1}>\lambda_{2}
\end{aligned}
$$

$$
\begin{aligned}
\sum_{u=1}^{b} n_{i l} n_{i^{\prime} l} & =2 \lambda_{1}\left(n_{1}+n_{2}\right)=2 \lambda_{1}(v-1) \quad \text { if } \lambda_{2}>\lambda_{1} \\
& =2 \lambda_{2}\left(n_{1}+n_{2}\right)=2 \lambda_{2}(v-1) \text { if } \lambda_{1}>\lambda_{2}
\end{aligned}
$$

The proofs of all identities are easy are omitted.

From Lemma (3.1), it follows that, for the design $d^{*}, \mathbf{C}_{d^{*}}$ is given by

$$
\mathbf{C}_{d^{*}}=\theta\left(\mathbf{I}_{v}-v^{-1} \mathbf{1}_{v} \mathbf{1}_{v}^{\prime}\right)
$$

where $\theta=\lambda_{1}(v-2)$ or $\lambda_{2}(v-2), \mathbf{I}_{v}$ is the identity matrix of order $v$ and $\mathbf{1}_{v}$ is the $v$ component vector of all 1 's.

From (3.4) it is easy to see that generalized inverse of $\mathbf{C}_{d^{*}}$ is.

$$
\mathbf{C}_{d^{*}}^{-}=\theta^{-1} \mathbf{I}_{v}
$$

It is obvious from (3.5) that $d^{*}$ is a variance balanced and therefore all elementary contrasts among gca effects are estimated under the assumption of homogeneous error variance across all blocks with a variance $2 \sigma^{2} / \theta$. Hence design $d^{*}$ is connected and has rank equal to $v-1$. Since design $d_{(2)}$ has blocks of unequal block sizes, therefore the error variance of $d_{(2)}$ will not be the same as of design $d_{(1)}$. Let $\sigma_{1}^{2}$ and $\sigma_{2}^{2}$ be the error variances of designs $d_{(1)}$ and $d_{(2)}$, respectively. Now we can interpret that all elementary contrasts among gca effects in designs $d_{(1)}$ and $d_{(2)}$ are estimated with a variances $\frac{2 \sigma_{1}^{2}}{\theta}$ and $\frac{2 \sigma_{2}^{2}}{\theta}$, respectively. Further the adjusted sum of squares due to gca effects is simply $\theta^{-1} \mathbf{Q}^{\prime} \mathbf{Q}=\theta^{-1}\left(Q_{1}^{2}+\ldots+Q_{v}^{2}\right)$, where $i=1,2 \ldots v, Q_{i}$ is the adjusted total of the $i$ th line; that is $Q_{i}$ is the $i$ th component of the vector $\mathbf{Q}$, defined in (3.3). We thus have the following result.

Theorem 3.1 The design $d^{*}$ (i.e. $d_{1}$ and $d_{2}$ ) is variance-balanced for general combining ability effects.

Now we take the optimality aspects. The optimality criterion is the minimization of average variance of the best linear unbiased estimators of all elementary comparisons between gca effects.

Let $\mathbf{D}\left(v, b, k_{1}, \ldots, k_{b}\right)$ denote the class of all connected block designs $d^{*}$ with $v$ lines, $b$ blocks such that $j$ th block is of size $k_{j}$. Similarly $\mathbf{D}_{0}(v, b, n)$ denote the class of all connected block designs $d^{*}$ with $v$ lines, $b$ blocks and $n$ experimental units. Here the block sizes are arbitrary but for a given design $d^{*}{ }_{\varepsilon} \mathbf{D}_{0}(v, b, n)$, the block sizes are equal.

Now using the following theorem (Parsad et al. 1999, page 41). 
Theorem 3.2 Let $d^{*} \in \mathbf{D}\left(v, b, k_{1}, \ldots, k_{b}\right)\left[\mathbf{D}_{0}(v, b, n)\right]$ be a block design for diallel crosses and suppose that $d^{*}$ satisfies

(i) Trace $\left(C_{d^{*}}\right)=2 \sum_{j=1}^{b} k_{j}-\sum_{j=1}^{b} \frac{1}{k_{j}}\left[2 k_{j}\left(2 x_{j}+1\right)-v x_{j}\left(x_{j}+1\right)\right]$ if and only if $n_{d^{*} i j}=x_{j}$ or $x_{j}+1$ for all $i=1, \ldots, v ; j=1, \ldots, b$, where $x_{j}$ is a positive integer. And for $n_{d^{*} i j}=0$ or 1 , this reduces to [Trace $\left(C_{d^{*}}\right)=2(n-b)$ ], where $n$ and $b$ are total number of experimental units and number of blocks in diallel cross design $\left[\mathbf{D}_{0}(v, b, n)\right]$, respectively.

(ii) $C_{d^{*}}$ is completely symmetric.

Then $d^{*}$ is universally optimal over $\mathbf{D}\left(v, b, k_{1}, \ldots, k_{b}\right)\left[\mathbf{D}_{0}(v, b, n)\right]$

For any member of $\mathbf{D}\left(v, b, k_{1}, \ldots, k_{b}\right)\left[\mathbf{D}_{0}(v, b, n)\right]$, we have Trace $\left(C_{d^{*}}\right)=\lambda_{2}(v-$ $1)(v-2)$ if $\lambda_{1}>\lambda_{2}$ or $\lambda_{1}(v-1)(v-2)$ if $\lambda_{2}>\lambda_{1}$ and for any member $\mathbf{D}_{0}(v, b, n)$ to be universally optimal, the Trace $\left(C_{d^{*}}\right)$ must be equal to $2(n-b)$, where $2(n-b)=$ $\lambda_{2}(v-1)^{2}$ if $\lambda_{1}>\lambda_{2}$ (or $\lambda_{1}(v-1)^{2}$ if $\left.\lambda_{2}>\lambda_{1}\right)$. The equality of Trace $\left(C_{d^{*}}\right)$ follows for any member of $\mathbf{D}\left(v, b, k_{1}, \ldots, k_{b}\right)$ but for any member of $\left[\mathbf{D}_{0}(v, b, n)\right]$, the Trace $\left(C_{d^{*}}\right)$ is less than $2(n-b)$.

Hence we have the following theorem.

Theorem 3.3 The designs $d_{2}$ obtained from $d_{(2),}$ a two associate PBIB designs, where none of the $\lambda$ 's is zero, are universally optimal over $\mathbf{D}\left(v, b, k_{1}, \ldots, k_{b}\right)$.

\section{Efficiency factor}

Now we will show that the designs $d_{(1)}$ and $d_{(2)}$ are optimal in the sense of Kempthorne (1956). If instead of the designs $d_{(1)}$ and $d_{(2)}$, one adopts a randomized complete block design with $r_{1}\left(r_{2}\right)$ blocks, each block having all the $v(v-1) / 2$ crosses , the $\mathbf{C}$ matrix of the randomized block design i.e. $\mathbf{C}_{\mathbf{R}}$-matrix can easily shown to be, see Dey and Midha (1996).

$$
\mathbf{C}_{\mathbf{R}}=r_{i}(v-2)\left(\mathbf{I}_{v}-v^{-1} \mathbf{1}_{v} \mathbf{1}^{\prime}{ }_{v}\right) \quad \text { where } i=1 \text { or } 2
$$

Hence the variance of the best linear unbiased estimator of any elementary contrast among gca effects in the case of randomized block experiment is $2 \sigma^{2} / r_{i}(v-2)$, where $\sigma^{2}$ is the per observation variance. Thus the efficiency factors $e_{1}$ and $e_{2}$, respectively of the design $d_{(1)}$ and $d_{(2)}$, relative to randomized complete block designs under the assumption of equal intrablock variances is given by

$$
e_{1}=\theta / r_{1}(v-2)=r_{1}(v-2) / r_{1}(v-2)=1
$$

and

$$
e_{2}=r_{2}(v-2) / r_{2}(v-2)=1
$$

where $\theta=r_{1}(v-2)\left(\right.$ or $\left.r_{2}(v-2)\right)$ for design $d_{(1)}\left(\right.$ or $\left.d_{(2)}\right)$.

We are also giving the list of practicable useful designs for $5 \leq v \leq 30$ in Table 1 . 


\section{Table 1}

\begin{tabular}{|c|c|c|c|c|c|c|c|}
\hline Sl. no. & $\begin{array}{l}\text { Ref. no. } \\
\text { of the } \\
\text { design }\end{array}$ & $\begin{array}{l}\text { No. of } \\
\text { lines }\end{array}$ & $\begin{array}{l}\text { No. of } \\
\text { blocks } \\
\text { to be } \\
\text { deleted }\end{array}$ & $\begin{array}{l}\text { No. of } \\
\text { crosses } \\
\text { to be } \\
\text { deleted }\end{array}$ & $\begin{array}{l}\text { No of } \\
\text { replication } \\
\text { of the } \\
\text { crosses }(r)\end{array}$ & $\begin{array}{l}\text { Total no. of } \\
\text { experimental } \\
\text { units }\end{array}$ & $\begin{array}{l}\text { Design names } \\
\text { reported by } \\
\text { different } \\
\text { authors }\end{array}$ \\
\hline 1 & $\mathrm{~S} 2$ & 6 & 1 & 3 & 2 & 30 & $\begin{array}{l}\text { F2, Parsad et al. } \\
\text { (1999) and Das } \\
\text { et al. (1998, } \\
\text { Th. 4.1) }\end{array}$ \\
\hline 2 & S19 & 8 & 1 & 4 & 4 & 112 & $\mathrm{~N}$ \\
\hline 3 & $\mathrm{~S} 23$ & 9 & 3 & 9 & 3 & 108 & $\begin{array}{l}\text { F2, Parsad et al. } \\
(1999)\end{array}$ \\
\hline 4 & $\mathrm{~S} 29$ & 12 & 4 & 12 & 2 & 132 & $\mathrm{~N}$ \\
\hline 5 & S33 & 14 & 2 & 7 & 2 & 182 & $\mathrm{~N}$ \\
\hline 6 & $\mathrm{~S} 42$ & 21 & 5 & 21 & 1 & 210 & $\begin{array}{l}\text { Ser. 1, Gupta and } \\
\text { Kageyama (1994) } \\
\text { and Sharma } \\
(2004)\end{array}$ \\
\hline $7^{\mathrm{a}}$ & S44 & 26 & 2.5 & 13 & 1 & 325 & $\begin{array}{l}\text { Ser. 2, Gupta and } \\
\text { Kageyama (1994) } \\
\text { and Sharma } \\
\text { (2004) }\end{array}$ \\
\hline 8 & S52 & 10 & 1 & 5 & 6 & 270 & $\mathrm{~N}$ \\
\hline 9 & S60 & 14 & 2 & 7 & 4 & 364 & $\mathrm{~N}$ \\
\hline 10 & S68 & 20 & 9 & 30 & 2 & 380 & $\mathrm{~N}$ \\
\hline 11 & $S 72$ & 26 & 3 & 13 & 2 & 650 & $\mathrm{~N}$ \\
\hline 12 & S90 & 21 & 6 & 21 & 3 & 630 & $\begin{array}{l}\text { F2, Parsad et al. } \\
\text { (1999) }\end{array}$ \\
\hline 13 & S93 & 30 & 7 & 30 & 2 & 870 & $\mathrm{~N}$ \\
\hline 14 & S99 & 12 & 1 & 6 & 8 & 528 & $\mathrm{~N}$ \\
\hline 15 & S104 & 15 & 10 & 30 & 5 & 525 & $\begin{array}{l}\text { F2, Parsad et al. } \\
(1999)\end{array}$ \\
\hline $16^{\mathrm{a}}$ & $\mathrm{S} 105$ & 18 & 2.5 & 9 & 5 & 765 & $\begin{array}{l}\text { F2, Parsad et al. } \\
(1999)\end{array}$ \\
\hline 17 & S111 & 22 & 3 & 11 & 4 & 924 & $\begin{array}{l}\text { F2, Parsad et al. } \\
\text { (1999) }\end{array}$ \\
\hline 18 & S115 & 30 & 3 & 60 & 2 & 870 & $\mathrm{~N}$ \\
\hline 19 & SR9 & 9 & 3 & 27 & 3 & 108 & $\begin{array}{l}\text { F2, Parsad et al. } \\
(1999)\end{array}$ \\
\hline 20 & SR68 & 12 & 4 & 48 & 2 & 132 & $\mathrm{~N}$ \\
\hline $21^{\mathrm{a}}$ & $\mathrm{R} 42$ & 6 & 0.5 & 3 & 1 & 15 & $\begin{array}{l}\text { Ser.2, Gupta and } \\
\text { Kageyama (1994) } \\
\text { and Sharma } \\
\text { (2004) }\end{array}$ \\
\hline 22 & R94 & 6 & 1 & 6 & 2 & 30 & $\begin{array}{l}\text { F2, Parsad et al. } \\
\text { (1999) }\end{array}$ \\
\hline 23 & R104 & 9 & 2 & 9 & 1 & 36 & $\begin{array}{l}\text { F1, Parsad et al. } \\
\text { (1999) and F5, } \\
\text { Das et al. (1998) }\end{array}$ \\
\hline
\end{tabular}


Table 1 continued

\begin{tabular}{|c|c|c|c|c|c|c|c|}
\hline Sl. no. & $\begin{array}{l}\text { Ref. no. } \\
\text { of the } \\
\text { design }\end{array}$ & $\begin{array}{l}\text { No. of } \\
\text { lines }\end{array}$ & $\begin{array}{l}\text { No. of } \\
\text { blocks } \\
\text { to be } \\
\text { deleted }\end{array}$ & $\begin{array}{l}\text { No. of } \\
\text { crosses } \\
\text { to be } \\
\text { deleted }\end{array}$ & $\begin{array}{l}\text { No of } \\
\text { replication } \\
\text { of the } \\
\text { crosses }(r)\end{array}$ & $\begin{array}{l}\text { Total no. of } \\
\text { experimental } \\
\text { units }\end{array}$ & $\begin{array}{l}\text { Design names } \\
\text { reported by } \\
\text { different } \\
\text { authors }\end{array}$ \\
\hline $24^{\mathrm{a}}$ & R109 & 12 & 0.5 & 6 & 1 & 66 & $\begin{array}{l}\text { Ser. 2, Gupta and } \\
\text { Kageyama (1994) } \\
\text { and Sharma } \\
(2004)\end{array}$ \\
\hline 25 & R133 & 8 & 3 & 12 & 2 & 56 & $\mathrm{~N}$ \\
\hline 26 & R134 & 8 & 3 & 24 & 2 & 56 & $\mathrm{~N}$ \\
\hline 27 & R137 & 9 & 2 & 9 & 2 & 72 & $\begin{array}{l}\text { F4, Das et al. } \\
(1998)\end{array}$ \\
\hline 28 & R139 & 10 & 1 & 5 & 2 & 90 & $\begin{array}{l}\text { F2, Parsad et al. } \\
(1999)\end{array}$ \\
\hline $29^{a}$ & R145 & 12 & 4.5 & 54 & 1 & 66 & $\begin{array}{l}\text { Ser. 2, Gupta and } \\
\text { Kageyama (1994) } \\
\text { and Sharma } \\
\text { (2004) }\end{array}$ \\
\hline 30 & R166 & 10 & 6 & 20 & 2 & 90 & $\begin{array}{l}\text { F2, Parsad et al. } \\
(1999)\end{array}$ \\
\hline 31 & R168 & 15 & 8 & 30 & 1 & 105 & $\begin{array}{l}\text { F1, Gupta and } \\
\text { Kageyama (1994) } \\
\text { and Sharma } \\
(2004)\end{array}$ \\
\hline 32 & $\mathrm{R} 170$ & 27 & 2 & 27 & 1 & 351 & $\begin{array}{l}\text { F1, Parsad et al. } \\
\text { (1999) and F5, } \\
\text { Das et al. (1998) }\end{array}$ \\
\hline $33^{\mathrm{a}}$ & R171 & 28 & 1.5 & 42 & 1 & 378 & $\begin{array}{l}\text { Ser. 2, Gupta and } \\
\text { Kageyama (1994) } \\
\text { and Sharma } \\
(2004)\end{array}$ \\
\hline 34 & R172 & 9 & 1 & 9 & 5 & 180 & $\begin{array}{l}\text { F2, Parsad et al. } \\
(1999)\end{array}$ \\
\hline 35 & R173 & 12 & 10 & 30 & 5 & 330 & $\begin{array}{l}\text { F2, Parsad et al. } \\
(1999)\end{array}$ \\
\hline $36^{\mathrm{a}}$ & R174 & 12 & 4.5 & 54 & 3 & 198 & $\begin{array}{l}\text { F2, Parsad et al. } \\
(1999)\end{array}$ \\
\hline 37 & $\mathrm{R} 175$ & 12 & 10 & 30 & 2 & 132 & $\begin{array}{l}\text { F2, Parsad et al. } \\
(1999)\end{array}$ \\
\hline $38^{\mathrm{a}}$ & R176 & 12 & 4.5 & 54 & 3 & 198 & $\mathrm{~N}$ \\
\hline $39^{\mathrm{a}}$ & R177 & 14 & 1.5 & 7 & 3 & 273 & $\mathrm{~N}$ \\
\hline $40^{\mathrm{a}}$ & R178 & 18 & 12.5 & 45 & 1 & 153 & $\begin{array}{l}\text { Ser. 2, Gupta and } \\
\text { Kageyama (1994) } \\
\text { and Sharma } \\
\text { (2004) }\end{array}$ \\
\hline 41 & R179 & 20 & 2 & 40 & 2 & 380 & $\mathrm{~N}$ \\
\hline 42 & R180 & 20 & 2 & 10 & 2 & 380 & $\mathrm{~N}$ \\
\hline $43^{a}$ & R186 & 12 & 0.5 & 6 & 5 & 330 & $\begin{array}{l}\text { F2, Parsad et al. } \\
(1999)\end{array}$ \\
\hline
\end{tabular}


Table 1 continued

\begin{tabular}{|c|c|c|c|c|c|c|c|}
\hline Sl. no. & $\begin{array}{l}\text { Ref. no. } \\
\text { of the } \\
\text { design }\end{array}$ & $\begin{array}{l}\text { No. of } \\
\text { lines }\end{array}$ & $\begin{array}{l}\text { No. of } \\
\text { blocks } \\
\text { to be } \\
\text { deleted }\end{array}$ & $\begin{array}{l}\text { No. of } \\
\text { crosses } \\
\text { to be } \\
\text { deleted }\end{array}$ & $\begin{array}{l}\text { No of } \\
\text { replication } \\
\text { of the } \\
\text { crosses }(r)\end{array}$ & $\begin{array}{l}\text { Total no. of } \\
\text { experimental } \\
\text { units }\end{array}$ & $\begin{array}{l}\text { Design names } \\
\text { reported by } \\
\text { different } \\
\text { authors }\end{array}$ \\
\hline 44 & R187 & 14 & 15 & 42 & 2 & 210 & $\mathrm{~N}$ \\
\hline 45 & R188 & 21 & 18 & 63 & 1 & 210 & $\begin{array}{l}\text { Ser. 1, Gupta and } \\
\text { Kageyama (1994) } \\
\text { and Sharma } \\
(2004)\end{array}$ \\
\hline 46 & R189 & 24 & 5 & 60 & 2 & 552 & $\mathrm{~N}$ \\
\hline 47 & R193 & 12 & 3 & 18 & 6 & 396 & $\mathrm{~N}$ \\
\hline 48 & R194 & 15 & 8 & 30 & 4 & 420 & $\begin{array}{l}\text { F2, Parsad et al. } \\
\text { (1999) }\end{array}$ \\
\hline 49 & R195 & 16 & 21 & 56 & 2 & 240 & $\begin{array}{l}\text { F2, Parsad et al. } \\
\text { (1999) }\end{array}$ \\
\hline 50 & R196 & 18 & 2 & 9 & 4 & 612 & $\mathrm{~N}$ \\
\hline 51 & R196 & 18 & 2 & 9 & 4 & 612 & $\mathrm{~N}$ \\
\hline $52^{\mathrm{a}}$ & R198 & 24 & 24.5 & 84 & 1 & 276 & $\begin{array}{l}\text { Ser. 2, Gupta and } \\
\text { Kageyama (1994) } \\
\text { and Sharma } \\
(2004)\end{array}$ \\
\hline 53 & R200 & 28 & 9 & 84 & 2 & 756 & $\begin{array}{l}\text { F2, Parsad et al. } \\
\text { (1999) }\end{array}$ \\
\hline 54 & R204 & 14 & 6 & 42 & 6 & 546 & $\begin{array}{l}\text { F2, Parsad et al. } \\
\text { (1999) }\end{array}$ \\
\hline 55 & R205 & 14 & 6 & 84 & 6 & 546 & $\begin{array}{l}\text { F2, Parsad et al. } \\
\text { (1999) }\end{array}$ \\
\hline 56 & R206 & 18 & 28 & 81 & 2 & 756 & $\begin{array}{l}\text { F2, Parsad et al. } \\
\text { (1999) }\end{array}$ \\
\hline 57 & R207 & 27 & 32 & 108 & 1 & 351 & $\begin{array}{l}\text { F1, Parsad et al. } \\
\text { (1999) and F5, } \\
\text { Das et al. (1998) }\end{array}$ \\
\hline $58^{\mathrm{a}}$ & T33 & 10 & 1.5 & 15 & 1 & 45 & $\begin{array}{l}\text { Ser. 2, Gupta and } \\
\text { Kageyama (1994) } \\
\text { and Sharma } \\
(2004)\end{array}$ \\
\hline 59 & T58 & 10 & 3 & 45 & 2 & 90 & $\begin{array}{l}\text { F2, Parsad et al. } \\
\text { (1999) }\end{array}$ \\
\hline $60^{\mathrm{a}}$ & T60 & 10 & 1.5 & 15 & 3 & 135 & $\mathrm{~N}$ \\
\hline 61 & T61 & 15 & 8 & 60 & 1 & 105 & $\begin{array}{l}\text { Ser. 1, Gupta and } \\
\text { Kageyama (1994) } \\
\text { and Sharma } \\
(2004)\end{array}$ \\
\hline 62 & $\mathrm{~T} 71$ & 10 & 3 & 15 & 4 & 180 & $\mathrm{~N}$ \\
\hline 63 & T84 & 15 & 8 & 60 & 4 & 420 & $\begin{array}{l}\text { F2, Parsad et al. } \\
\text { (1999) }\end{array}$ \\
\hline 64 & T94 & 21 & 15 & 105 & 3 & 630 & $\begin{array}{l}\text { F2, Parsad et al. } \\
\text { (1999) }\end{array}$ \\
\hline
\end{tabular}


Table 1 continued

\begin{tabular}{|c|c|c|c|c|c|c|c|}
\hline Sl. no. & $\begin{array}{l}\text { Ref. no. } \\
\text { of the } \\
\text { design }\end{array}$ & $\begin{array}{l}\text { No. of } \\
\text { lines }\end{array}$ & $\begin{array}{l}\text { No. of } \\
\text { blocks } \\
\text { to be } \\
\text { deleted }\end{array}$ & $\begin{array}{l}\text { No. of } \\
\text { crosses } \\
\text { to be } \\
\text { deleted }\end{array}$ & $\begin{array}{l}\text { No of } \\
\text { replication } \\
\text { of the } \\
\text { crosses }(r)\end{array}$ & $\begin{array}{l}\text { Total no. of } \\
\text { experimental } \\
\text { units }\end{array}$ & $\begin{array}{l}\text { Design names } \\
\text { reported by } \\
\text { different } \\
\text { authors }\end{array}$ \\
\hline 65 & T95 & 21 & 5 & 105 & 4 & 820 & $\mathrm{~N}$ \\
\hline 66 & LS26 & 9 & 2 & 18 & 1 & 36 & $\begin{array}{l}\text { F1, Parsad et al. } \\
\text { (1999) and F5, } \\
\text { Das et al. (1998) }\end{array}$ \\
\hline 67 & LS49 & 9 & 2 & 18 & 2 & 72 & $\begin{array}{l}\text { F4, Das et al. } \\
(1998)\end{array}$ \\
\hline 68 & LS72 & 9 & 2 & 18 & 2 & 72 & $\begin{array}{l}\text { F4, Das et al. } \\
\text { (1998) }\end{array}$ \\
\hline 69 & LS83 & 16 & 6 & 48 & 2 & 240 & $\begin{array}{l}\text { F2, Parsad et al. } \\
\text { (1999) }\end{array}$ \\
\hline 70 & LS99 & 16 & 9 & 72 & 3 & 360 & $\begin{array}{l}\text { F2, Parsad et al. } \\
\text { (1999) }\end{array}$ \\
\hline 71 & LS100 & 16 & 6 & 48 & 3 & 360 & $\begin{array}{l}\text { F2, Parsad et al. } \\
(1999)\end{array}$ \\
\hline 72 & LS101 & 25 & 4 & 100 & 2 & 600 & $\mathrm{~N}$ \\
\hline 73 & LS116 & 16 & 6 & 48 & 4 & 480 & $\mathrm{~N}$ \\
\hline 74 & LS117 & 25 & 12 & 100 & 2 & 600 & $\mathrm{~N}$ \\
\hline 75 & C12 & 5 & 1 & 5 & 1 & 10 & $\begin{array}{l}\text { F1, Parsad et al. } \\
(1999) \text { and F5, } \\
\text { Das et al. (1998) }\end{array}$ \\
\hline 76 & $\mathrm{C} 23$ & 13 & 3 & 39 & 2 & 156 & $\mathrm{~N}$ \\
\hline 77 & $\mathrm{C} 24$ & 13 & 3 & 39 & 3 & 234 & $\mathrm{~N}$ \\
\hline 78 & $\mathrm{C} 25$ & 29 & 7 & 203 & 1 & 406 & $\begin{array}{l}\text { F1, Parsad et al. } \\
\text { (1999) and F4, } \\
\text { Das et al. (1998) }\end{array}$ \\
\hline 79 & C26 & 17 & 4 & 68 & 3 & 408 & $\begin{array}{l}\text { F2, Parsad et al. } \\
(1999)\end{array}$ \\
\hline 80 & $\mathrm{C} 27$ & 29 & 7 & 203 & 1 & 406 & $\begin{array}{l}\text { F1, Parsad et al. } \\
\text { (1999) and F5, } \\
\text { Das et al. (1998) }\end{array}$ \\
\hline 81 & C28 & 17 & 4 & 68 & 4 & 544 & $\mathrm{~N}$ \\
\hline 82 & C29 & 13 & 3 & 39 & 7 & 468 & $\begin{array}{l}\text { F2, Parsad et al. } \\
\text { (1999) }\end{array}$ \\
\hline 83 & M34 & 16 & 6 & 48 & 4 & 480 & $\mathrm{~N}$ \\
\hline $84^{\mathrm{a}}$ & M38 & 26 & 7.5 & 195 & 3 & 975 & $\begin{array}{l}\text { F2, Parsad et al. } \\
(1999)\end{array}$ \\
\hline 85 & M39 & 27 & 32 & 216 & 1 & 351 & $\begin{array}{l}\text { F1, Parsad et al. } \\
\text { (1999) and F5, } \\
\text { Das et al. (1998) }\end{array}$ \\
\hline
\end{tabular}

$N$ new, Ser. series, $F$ family

${ }^{a}$ Universally optimal designs 


\section{Conclusion}

Optimal block designs with proper and non-proper settings have been proposed for CDC system IV using some PBIB designs. The non-proper setting designs found to be universally optimal in the sense of Kiefer (1975) and proper and non-proper setting designs are optimal in the sense of Kempthorne (1956). These designs retain full efficiency for the estimation of the contrast of interest. We investigated 85 PBIB designs (Clatworthy 1973). Out of which 20 and 29 PBIB designs gave block designs for CDC experiment in which each cross is replicated once and twice, respectively and in rest of the designs each cross is replicated more than twice. These designs are in the range of $5 \leq v \leq 30$, except for $v=11,17,19,22$, and 23 .

Acknowledgments The authors wish to thank the Editor and both the referees for their valuable comments and suggestions that greatly improved the presentation of the paper.

Open Access This article is distributed under the terms of the Creative Commons Attribution Noncommercial License which permits any noncommercial use, distribution, and reproduction in any medium, provided the original author(s) and source are credited.

\section{References}

Clatworthy WH (1973) Tables of two-associate-class partially balanced designs. Applied maths. Ser. No. 63. National Bureau of Standards, Washington D.C.

Das A, Dey A, Dean A (1998) Optimal design for diallel cross experiments. Statist Prob Lett 36:427-436

Dey A (1986) Theory of block designs. Halsted Press, New York

Dey A, Midha CK (1996) Optimal designs for diallel crosses. Biometrika 83(2):484-489

Griffing B (1956) Concept of general and specific combining ability in relation to diallel crossing systems. Aust J Biol Sci 9:463-93

Gupta S, Kageyama S (1994) Optimal complete diallel crosses. Biometrika 81:420-424

Kiefer J (1975) Construction and optimality of generalized Youden designs. In: Srivastava JN (ed) A survey of statistical design and linear models. North Hollond, Amsterdam, pp 333-53

Kempthorne O (1956) The theory of diallel crosses. Genetics 41:451-459

Kempthorne O, Curnow RN (1961) The partial diallel cross. Biometrics 17:229-250

Mukerjee R (1997) Optimal partial diallel crosses. Biometrika 84(4):937-946

Parsad R, Gupta VK, Srivastava R (1999) Optimal designs for diallel crosses. J Soc Stat Comput Appl 1:35-52

Sharma MK (2004) Optimal complete diallel cross. Recent advances in mating designs. Dhanpat Rai \& Company(P) Ltd, New Delhi 